\title{
Properties of heat induced blend gel of Peruvian squid (Dosidicus gigas) myofibril protein fortified with millet (Panicum miliaceum $L$.) flour
}

\author{
Tian Wang ${ }^{1}$, Xuepeng $\mathrm{Li}^{1}$, Jing Xie ${ }^{2}$, Jianrong $\mathrm{Li}^{1}$ and Geng $\mathrm{Mi}^{1,2, \mathrm{a}}$ \\ ${ }^{1}$ College of Food Science and Technology, Bohai University, 121013 Jinzhou, Liaoning, China \\ ${ }^{2}$ College of Food Science and Technology, Shanghai Ocean University, 201306 Shanghai, China
}

\begin{abstract}
Weak gelation ability and simple nutrient composition of squid myofibril protein limits its further development in surimi production. Millet flour is rich in nutrients and has a good viscoelasticity after heating. Physicochemical properties of Peruvian squid myofibril protein based blend gel fortified with millet four were studied. Rheological test results showed that all blend gels exhibit solid-like characters. With the addition of millet flour, the composite modulus of all the samples showed a trend of decreasing first and then increasing. The minimum value appeared around $48^{\circ} \mathrm{C}$. Moreover, it was found that gel strength, water holding capacity, hardness, gumminess and chewiness showed a trend of increasing at first and then decreasing. The blend gel with $4 \%$ millet flour addition exhibit good performance in those testing. The subsequent analysis of water distribution further explained and proved the mechanism. In summary, the blend gel of squid myofibril protein fortified with $4 \%$ of millet flour addition was considered the most suitable amount for enhancing the quality of blend gel.
\end{abstract}

\section{Introduction}

Consumption of surimi food is one of the most distinguished cultures prevalent in Asia ${ }^{[1-2]}$. Peruvian Squid contains a large amount of salt-soluble protein and a low level of fat, making it an ideal source for surimi products. However, the weak gel strength and simple nutrient composition limits its further development. Millet flour (MF) is a popular health raw material for product cereal food, especially in the north of China. It has a favourable natural yellow colour and contains a lot of wholesome ingredients such as unsaturated fatty acid, dietary fiber, vitamin E, Iron and phosphorus [ 3 ]. Moreover, it was reported that the MF is significantly richer in essential amino acids than wheat flour ${ }^{[4]}$. There are two main types of MF according to the amylopectin content ${ }^{[5]}$. Panicum miliaceum $L$ contains a higher proportion of amylopectin, which makes it exhibit higher viscoelasticity after cooking. Therefore, MF has potential application value as a functional additive. Adding MF into surimi can not only reduce the cost, enhance nutrition, but also has a potential ability to improve the quality of products. However, there is still a lack of relevant research.

In this study, the different levels of MF were added to Peruvian squid surimi and then formed gels after experiencing the heat process. The gel properties, chewing characteristics, moisture distribution and rheological properties of blend gels were investigated. The results of this research will provide useful information for the further development and utilization of $\mathrm{MF}$, and provide reference for the development of additives with improved gel products.

\section{Materials and methods}

\subsection{Materials}

Peruvian squid were purchased from a local Aquatic Products Market. The raw MF was purchased from Inner Mongolia Mengqing Agricultural Technology Development Co., Ltd. The starch content of the MF was $70-74 \mathrm{~g} / 100 \mathrm{~g}$, and the protein content was $12-14 \mathrm{~g} / 100 \mathrm{~g}$. All chemicals used were of analytical grade.

\subsection{Preparation of MP/MF blends}

The squid was thawed for $5 \mathrm{~min}$ and then cut into slices of $1 \mathrm{~mm}$ thickness. After soaking in 5\% sodium bicarbonate at $4^{\circ} \mathrm{C}$ for $30 \mathrm{~min}$, and then carrying out dehydration treatment. The prepared fish was put into a vacuum freezing chopper (UMC5, Stephan Machinery Co., Hameln, Germany). Then the slices were chopped at $1500 \mathrm{rpm}$ for $2 \mathrm{~min}$ at $4^{\circ} \mathrm{C}$ and $6 \mathrm{mbar}$. About $3 \% \mathrm{NaCl}$ and $4{ }^{\circ} \mathrm{C}$ water was added to obtain $80 \%$ moisture of the myofibril protein (MP), and then continue chopped at $1500 \mathrm{rpm}$ for $2 \mathrm{~min}$. Finally, different levels of MF were added $(0 \%, 1 \%, 2 \%, 4 \%, 6 \%, 8 \%$ and $15 \%)$, and chopped

${ }^{\text {a } C o r r e s p o n d i n g ~ a u t h o r ' s ~ e-m a i l: ~ m i g e n g 1979 @ b h u . e d u . c n ~}$ 
for $5 \mathrm{~min}$ at $3000 \mathrm{rpm}$. The blend samples were marked as $\mathrm{PF}_{0}, \mathrm{PF}_{1}, \mathrm{PF}_{2}, \mathrm{PF}_{4}, \mathrm{PF}_{6}, \mathrm{PF}_{8}, \mathrm{PF}_{15}$, respectively.

\subsection{Determination of rheological properties}

The rheological properties of the raw blends were measured according to the method of Fan et al. ${ }^{[6]}$. The complex shear modulus $\left(\left|\mathrm{G}^{*}\right|\right)$ is calculated according to the following equation:

$$
\left|G^{*}\right|=\sqrt{\left(G^{\prime}\right)^{2}+\left(G^{\prime \prime}\right)^{2}}
$$

\subsection{Gel strength and cooking properties}

The prepared blend paste was extruded into a plastic casing with a diameter of $30 \mathrm{~mm}$. After that, it was heated at $90^{\circ} \mathrm{C}$ for $20 \mathrm{~min}$, put immediately in $0^{\circ} \mathrm{C}$ water for $10 \mathrm{~min}$, then all the samples were stored in $4^{\circ} \mathrm{C}$ refrigerator for $12 \mathrm{~h}$ before testing ${ }^{[7]}$. The gel strength of the sample was measured by the method of Chen et al. ${ }^{[8]}$. The water holding capacity (WHC) of the sample was determined by a centrifugation method ${ }^{[9]}$. The whiteness was measured by the method of Petcharat et al. ${ }^{[10]}$.

\subsection{Chewing properties}

The TPA test was measured according to the method of Alipour et al. ${ }^{[11]}$.

\subsection{Low-field NMR}

The spin-spin relaxation time $\mathrm{T}_{2}$ was measured by the method of Song et al. ${ }^{[12]}$.

\subsection{Statistical analysis}

All the results were represented by mean \pm std. (standard deviation). Statistical analysis was performed using IBM SPSS 22.0 (SPSS Inc, Chicago, USA). All experiments were repeated at least 3 times.

\section{Results and discussion}

\subsection{Rheological properties}

The results of temperature sweep of the gel are shown in Figure 1. The complex shear modulus $\left(\left|\mathrm{G}^{*}\right|\right)$ is a combination parameter describing the intensity of the gel, a higher $\left|\mathrm{G}^{*}\right|$ value indicates a high-intensity gel. Tan $\delta$ $\left(G^{\prime \prime} / G^{\prime}\right)<1$ indicates that the elasticity of the gel is better than the viscosity ${ }^{[13]}$. In the whole gel heating period, the $\left|G^{*}\right|$ of all samples showed a trend of decreasing first and then increasing. It was found when all the samples were heated to about $48^{\circ} \mathrm{C}$, the $\left|\mathrm{G}^{*}\right|$ showed its lowest value. Previous studies have shown that there are large amounts of metallo-proteinase in squid, which will be activated around $40-50^{\circ} \mathrm{C}$ and damage the structure of protein network ${ }^{[14]}$. On the one hand, with the temperature increasing, the $\left|G^{*}\right|$ of the blends increased obviously. It is assumed that the protein network gradually formed. On the other hand, as the amount of MF added increased, it can be seen the $\left|\mathrm{G}^{*}\right|$ shown a trend of decreasing first and then increasing. We speculated that there was a destructive effect of MF on the protein network. But at a high addition ratio, the starch in the MF formed its own continuous network, which enhanced the strength of the blend.

Tan $\delta$ represents the ratio of the elastic modulus to the viscous modulus of the blend. It can be seen from the result that the Tan $\delta$ of all samples showed the maximum value around $35^{\circ} \mathrm{C}$, which may be due to the looseness of salt-soluble protein tail denaturation and unwinding at the temperature ${ }^{[15]}$. In addition, it can be seen that the Tan $\delta$ of the blends increased obviously with the increase of $\mathrm{MF}$ at the temperature of $50^{\circ} \mathrm{C}$, and then began to decline near $80^{\circ} \mathrm{C}$, finally tended to a similar value. This may be because the starch in the MF began to absorb water and swell around $50^{\circ} \mathrm{C}$, and the viscosity of the system increased. When heated to around $80^{\circ} \mathrm{C}$, starch gelatinization occurs, where the amylose in the system begins to crosslink, and the viscosity modulus of the system gradually decreases while the elastic modulus increases.
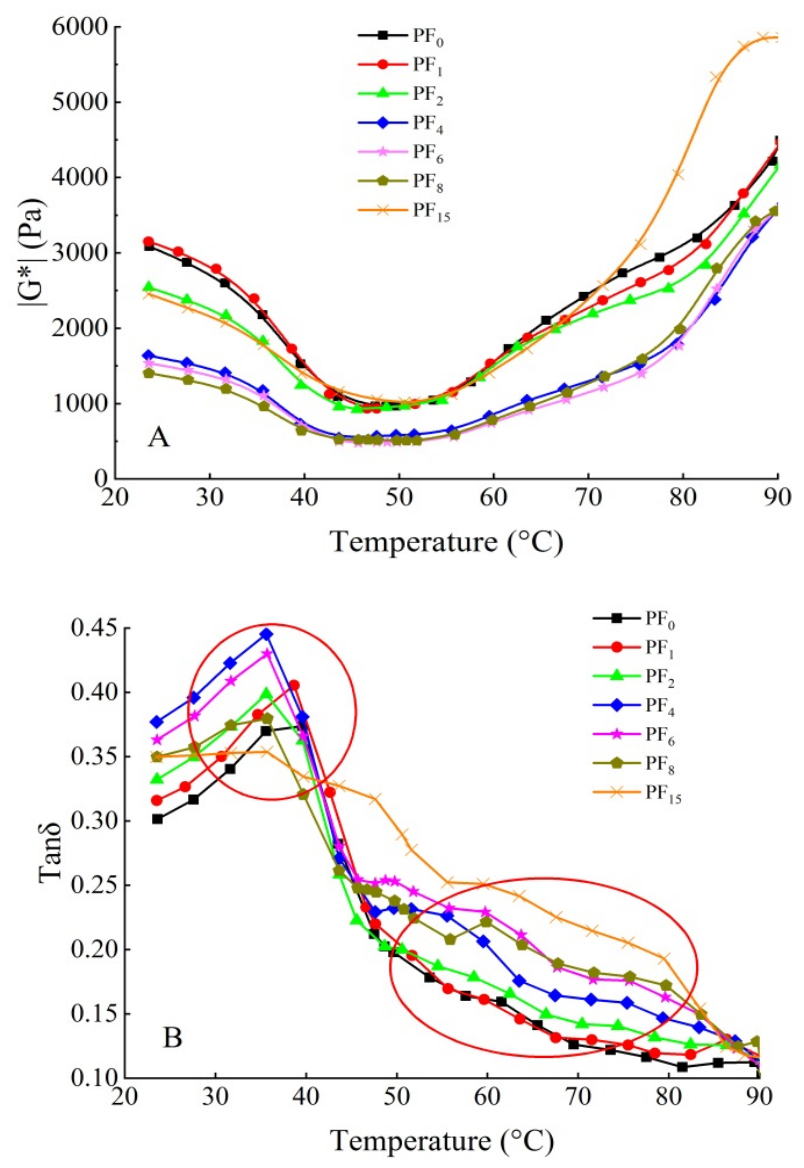

Figure 1. Effects of heating $\left(5^{\circ} \mathrm{C} / \mathrm{min}\right)$ on (A) complex shear modulus $\left(\left|\mathrm{G}^{*}\right|\right)$ versus temperature $\left({ }^{\circ} \mathrm{C}\right)$; and (B) loss factor $(\tan \delta)$ versus temperature $\left({ }^{\circ} \mathrm{C}\right)$ for Peruvian squid MP added with different concentrations of MF.

The MP added with different amounts of MF $(0 \%, 1 \%, 2 \%$, $4 \%, 6 \%, 8 \%$ and $15 \%$ ), was marked as $\mathrm{PF}_{0}, \mathrm{PF}_{1}, \mathrm{PF}_{2}, \mathrm{PF}_{4}, \mathrm{PF}_{6}$, $\mathrm{PF}_{8}, \mathrm{PF}_{15}$, respectively. 


\subsection{Cooking properties}

The cooking properties of MP-MF blend gels are shown in Table 1. The results suggest that the gel strength increased first and then decreased with the addition of MF. At the addition level of MF was 4\%, the gel strength increased its maximum value of $976.00 \mathrm{~g} \cdot \mathrm{mm}$. At low MF levels of samples like $\mathrm{PF}_{1}$ to $\mathrm{PF}_{2}$, we speculate that MP formed a continuous network, and starch act as filler, which had been reported to have a significant effect in increasing gel strength ${ }^{[16]}$. However, too much of MF would reduce the gel strength. The millet flour used in our experiment was rich in amylopectin, which could cause the MF to exhibit higher viscidity after being cooked. This may account for the decrease in gel strength of samples like $\mathrm{PF}_{6}-\mathrm{PF}_{15}$.

It can be seen that the WHC of the gels also show a trend of first increasing and then decreasing. It was found when the additional amount of MF was $4 \%$, the WHC of the gel reached the maximum value of $80.04 \%$. This may be related to the structure of protein network of MP. Moreover, the addition of MF can significantly $(\mathrm{P}<0.05)$ reduces the whiteness of MP gels (except for the 1\% addition of MF). This may be due to the strong yellow colour of MF. Similar results also were described by Romero et al. ${ }^{[17]}$, who used MF to make pasta and results indicated that the carotenoids and lutein contained in MF make the noodles attractive yellow.

Table 1. Gel strength and cooking properties of Peruvian squid MP added with different concentrations of MF.

\begin{tabular}{cccc}
\hline Treatment & $\begin{array}{c}\text { Gel strength } \\
(\mathbf{g} \cdot \mathbf{m m})\end{array}$ & WHC (\%) & Whiteness \\
\hline $\mathrm{PF}_{0}$ & $714.47 \pm 16.00^{\mathrm{d}}$ & $69.71 \pm 1.02^{\mathrm{c}}$ & $79.92 \pm 0.35^{\mathrm{a}}$ \\
$\mathrm{PF}_{1}$ & $808.53 \pm 29.07^{\mathrm{c}}$ & $73.78 \pm 1.84^{\mathrm{bc}}$ & $79.83 \pm 0.24^{\mathrm{a}}$ \\
$\mathrm{PF}_{2}$ & $904.32 \pm 24.40^{\mathrm{b}}$ & $76.80 \pm 1.34^{\mathrm{b}}$ & $77.46 \pm 0.16^{\mathrm{b}}$
\end{tabular}

$\begin{array}{cccc}\mathrm{PF}_{4} & 976.00 \pm 3.93^{\mathrm{a}} & 80.04 \pm 0.15^{\mathrm{a}} & 76.62 \pm 0.24^{\mathrm{bc}} \\ \mathrm{PF}_{6} & 822.17 \pm 2.82^{\mathrm{c}} & 79.78 \pm 0.57^{\mathrm{a}} & 76.23 \pm 0.41^{\mathrm{c}} \\ \mathrm{PF}_{8} & 565.31 \pm 16.85^{\mathrm{e}} & 78.98 \pm 1.11^{\mathrm{ab}} & 73.40 \pm 0.38^{\mathrm{d}} \\ \mathrm{PF}_{15} & 408.56 \pm 18.90^{\mathrm{f}} & 76.96 \pm 0.52^{\mathrm{b}} & 68.44 \pm 1.91^{\mathrm{e}}\end{array}$

${ }^{a}$ Different letters within the same column mean significant difference $(\mathrm{p}<0.05)$ between mean value.

${ }^{\mathrm{b}}$ The MP added with different amounts of MF $(0 \%, 1 \%, 2 \%$, $4 \%, 6 \%, 8 \%$ and $15 \%$ ), was marked as $\mathrm{PF}_{0}, \mathrm{PF}_{1}, \mathrm{PF}_{2}, \mathrm{PF}_{4}, \mathrm{PF}_{6}$, $\mathrm{PF}_{8}, \mathrm{PF}_{15}$, respectively.

\subsection{Chewing properties}

The TPA test is also called a two-bite test. It simulates the bite movement of the human mouth, which is equipped with a probe to compress the sample twice to explore the changes of the sample when it is chewed. The chewing properties of the blend gels are shown in Table 2. The hardness, gumminess and chewiness of the gels first increased and then decreased with the increasing additional level of MF. When MF was $4 \%$, the hardness, gumminess and chewiness reached the maximum values, which were $3276.53 \mathrm{~g}, 2530.28 \mathrm{~g}$ and $2244.44 \mathrm{~g}$, respectively. When the additional amount exceeds $4 \%$, the chewing properties of the gels became increasingly worse. The results are similar to the study of $\mathrm{Yu}$ et al. ${ }^{[18]}$, their result showed that $15 \%$ acetylated distarch phosphate added into soy protein showed a similar trend. The reason for this reduced effect may be caused by destruction of MF on the network of MP.

Furthermore, the increasing level of MF of the blend samples leads to competition between protein and starch for water molecules, and it may hinder the MP to access enough water in order to form a three-dimensional gel network by heating processing ${ }^{[11,19]}$.

Table 2. Chewing properties of Peruvian squid MP added with different concentrations of MF.

\begin{tabular}{ccccccc}
\hline Treatment & Hardness(g) & Springiness & Cohesiveness & Gumminess(g) & Chewiness(g) & Resilience \\
\hline $\mathrm{PF}_{0}$ & $2403.29 \pm 116.21^{\mathrm{cd}}$ & $0.89 \pm 0.00^{\mathrm{bc}}$ & $0.79 \pm 0.02^{\mathrm{ab}}$ & $1896.05 \pm 114.71^{\mathrm{cd}}$ & $1691.00 \pm 92.98^{\mathrm{c}}$ & $0.48 \pm 0.01^{\mathrm{a}}$ \\
$\mathrm{PF}_{1}$ & $2928.63 \pm 39.86^{\mathrm{b}}$ & $0.89 \pm 0.02^{\mathrm{bc}}$ & $0.77 \pm 0.00^{\mathrm{b}}$ & $2258.65 \pm 38.08^{\mathrm{b}}$ & $2015.33 \pm 50.02^{\mathrm{b}}$ & $0.45 \pm 0.00^{\mathrm{b}}$ \\
$\mathrm{PF}_{2}$ & $2497.95 \pm 30.52^{\mathrm{c}}$ & $0.87 \pm 0.01^{\mathrm{c}}$ & $0.77 \pm 0.01^{\mathrm{b}}$ & $1933.36 \pm 35.97^{\mathrm{c}}$ & $1686.27 \pm 52.65^{\mathrm{c}}$ & $0.46 \pm 0.01^{\mathrm{b}}$ \\
$\mathrm{PF}_{4}$ & $3276.53 \pm 83.40^{\mathrm{a}}$ & $0.89 \pm 0.00^{\mathrm{bc}}$ & $0.77 \pm 0.00^{\mathrm{b}}$ & $2530.28 \pm 68.27^{\mathrm{a}}$ & $2244.44 \pm 54.34^{\mathrm{a}}$ & $0.45 \pm 0.00^{\mathrm{b}}$ \\
$\mathrm{PF}_{6}$ & $2303.66 \pm 0.16^{\mathrm{d}}$ & $0.92 \pm 0.01^{\mathrm{a}}$ & $0.78 \pm 0.00^{\mathrm{ab}}$ & $1794.69 \pm 9.90^{\mathrm{d}}$ & $1658.80 \pm 35.09^{\mathrm{c}}$ & $0.45 \pm 0.00^{\mathrm{b}}$ \\
$\mathrm{PF}_{8}$ & $1070.80 \pm 19.83^{\mathrm{f}}$ & $0.91 \pm 0.01^{\mathrm{ab}}$ & $0.80 \pm 0.00^{\mathrm{a}}$ & $855.88 \pm 13.49^{\mathrm{f}}$ & $779.35 \pm 24.94^{\mathrm{e}}$ & $0.49 \pm 0.01^{\mathrm{a}}$ \\
$\mathrm{PF}_{15}$ & $1655.62 \pm 9.81^{\mathrm{e}}$ & $0.91 \pm 0.00^{\mathrm{ab}}$ & $0.77 \pm 0.01^{\mathrm{b}}$ & $1272.57 \pm 3.57^{\mathrm{e}}$ & $1158.45 \pm 2.62^{\mathrm{d}}$ & $0.46 \pm 0.01^{\mathrm{b}}$ \\
\hline
\end{tabular}

${ }^{\mathrm{a}}$ Different letters within the same column mean significant difference $(\mathrm{p}<0.05)$ between mean value.

${ }^{\mathrm{b}}$ The MP added with different amounts of MF $(0 \%, 1 \%, 2 \%, 4 \%, 6 \%, 8 \%$ and $15 \%)$, was marked as $\mathrm{PF}_{0}, \mathrm{PF}_{1}, \mathrm{PF}_{2}, \mathrm{PF}_{4}, \mathrm{PF}_{6}, \mathrm{PF}_{8}$, $\mathrm{PF}_{15}$, respectively.

\subsection{Water distribution analysis}

The distribution of spin-spin relaxation time $\mathrm{T}_{2}$ of the blend gels is shown in Figure 2, and their corresponding 
proportions are shown in Table 3. The results show that the proportion of $\mathrm{P}_{22}$ increased with the increase of MF. That may be due to water absorption and swelling of the starch in MF, which breaks the internal hydrogen bond and increases the monolayer of molecular water on the molecular surface. $\mathrm{P}_{23}$ showed an obvious trend of increasing at first and then decreasing. The maximum value appeared when $4 \% \mathrm{MF}$ was added. We speculate that the starch in the MF has formed an interpenetrating gel network due to thermodynamic incompatibility with the salt-soluble proteins, which enhances the water retention capacity of the blend ${ }^{[6]}$. However, the starch in the MF may damage the gel network of the blend with the increase of the amount of MF, which reduces the water content in the network. The results are consistent with the previous studies results of Nishizawa et al. ${ }^{[20]}$ and the WHC results in section 3.2.

Table 3. Peak ratio of populations of Peruvian squid MP added with different concentrations of MF.

\begin{tabular}{|c|c|c|c|}
\hline $\begin{array}{l}\text { Treat- } \\
\text { ment }\end{array}$ & $P_{22}(\%)$ & $P_{23}(\%)$ & $\mathbf{P}_{24}(\%)$ \\
\hline $\mathrm{PF}_{0}$ & $1.13 \pm 0.08^{\mathrm{e}}$ & $92.61 \pm 0.25^{\mathrm{d}}$ & $5.55 \pm 0.40^{\mathrm{a}}$ \\
\hline $\mathrm{PF}_{1}$ & $1.11 \pm 0.12^{\mathrm{e}}$ & $93.75 \pm 0.05^{\mathrm{b}}$ & $2.90 \pm 0.10^{\mathrm{bc}}$ \\
\hline $\mathrm{PF}_{2}$ & $1.38 \pm 0.15^{\mathrm{de}}$ & $94.43 \pm 1.02^{\mathrm{abc}}$ & $3.88 \pm 1.16^{\mathrm{b}}$ \\
\hline $\mathrm{PF}_{4}$ & $1.73 \pm 0.11^{\mathrm{d}}$ & $94.47 \pm 0.12^{\mathrm{a}}$ & $2.91 \pm 0.20^{\mathrm{b}}$ \\
\hline $\mathrm{PF}_{6}$ & $2.32 \pm 0.31^{\mathrm{c}}$ & $93.95 \pm 0.80^{\mathrm{abc}}$ & $3.27 \pm 1.11^{\mathrm{b}}$ \\
\hline $\mathrm{PF}_{8}$ & $2.94 \pm 0.12^{b}$ & $93.54 \pm 1.71^{\mathrm{abc}}$ & $1.71 \pm 0.00^{\mathrm{d}}$ \\
\hline $\mathrm{PF}_{15}$ & $3.31 \pm 0.45^{\mathrm{a}}$ & $93.30 \pm 1.12^{\mathrm{c}}$ & $2.19 \pm 0.75^{\mathrm{cd}}$ \\
\hline \multicolumn{4}{|c|}{$\begin{array}{l}{ }^{\mathrm{a}} \text { Different letters within the same column mean significant } \\
\text { difference }(\mathrm{p}<0.05) \text { between mean value. } \\
{ }^{\mathrm{b}} \text { The MP added with different amounts of } \mathrm{MF}(0 \%, 1 \%, 2 \% \text {, } \\
4 \%, 6 \%, 8 \% \text { and } 15 \%) \text {, was marked as } \mathrm{PF}_{0}, \mathrm{PF}_{1}, \mathrm{PF}_{2}, \mathrm{PF}_{4}, \mathrm{PF}_{6} \text {, } \\
\mathrm{PF}_{8}, \mathrm{PF}_{15} \text {, respectively. }\end{array}$} \\
\hline
\end{tabular}

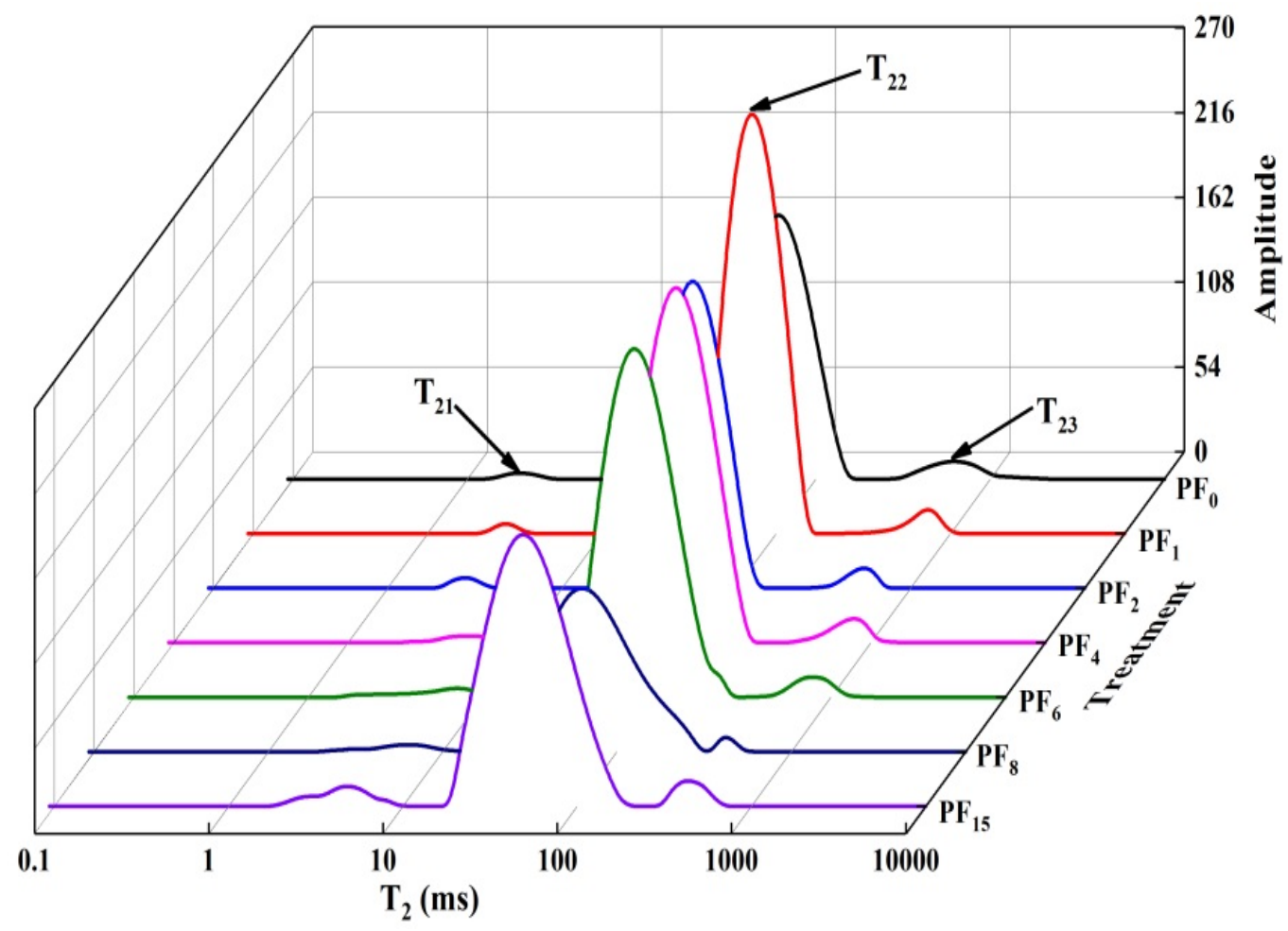

Figure 2. Water states of Peruvian squid MP added with different concentrations of MF.

The MP added with different amounts of $\mathrm{MF}(0 \%, 1 \%, 2 \%, 4 \%, 6 \%, 8 \%$ and $15 \%)$, was marked as $\mathrm{PF}_{0}, \mathrm{PF}_{1}, \mathrm{PF}_{2}, \mathrm{PF}_{4}, \mathrm{PF}_{6}, \mathrm{PF}_{8}, \mathrm{PF}_{15}$, respectively.

\section{Conclusions}

This work mainly studied the effect of millet flour on the quality of squid myofibrillar protein blend gel, and demonstrated a feasible solution for preparing a new type of surimi product. The rheological analysis showed that the complex shear modulus of all samples showed a trend of first increase and then decrease and the lowest values appeared around $48^{\circ} \mathrm{C}$. Moreover, all samples showed solid-like character after the blends experienced heat processing. With the increased addition of MF, the gel strength, WHC, and hardness, gumminess and chewiness of all samples also showed a trend of increasing at first and then decreasing. MF gave the blends a bright yellow colour. Furthermore, according to the results of moisture distribution analysis, 4\% MF addition will enhance the water retention capacity of blend gel. In terms of application, $4 \%$ addition of $\mathrm{MF}$ was considered to be the most suitable for the production of blend gel products. 


\section{Acknowledgments}

This work was supported by the National Natural Science Foundation of China (31972107, U20A2067).

\section{References}

1. J.S. Córdova-Ramos, U. Gonzales-Barron, L.M. Cerrón-Mallqui, LWT-Food. Sci. Technol., 93, 506-510 (2018)

2. R.R. Olivas, O.R. Sández, N.F. Haard, R.P. Aguilar, J.M.E. Brauer, Eur. Food. Res. Technol., 219, 312-315 (2004)

3. K. Lorenz, W. Dilsaver, L. Bates, Cereal. Chem., 57, 16-20 (1980)

4. J. Kalinova, J. Moudry, Plant. Food. Hum. Nutr., 61, 43-47 (2006)

5. Q.H. Yang, P.P. Zhang, Y. Qu, X.L. Gao, J.B. Liang, P. Yang, B.L. Feng, Food. Chem., 257, 271-278 (2018)

6. M.C. Fan, T. Hu, S.M. Zhao, S.B. Xiong, J. Xie, Q.L. Huang, Food. Chem., 218, 221-230 (2017)

7. F.Y. Sun, Q.L. Huang, T. Hu, S.B. Xiong, S.M. Zhao, Int. J. Biol. Macromol., 64, 17-24 (2014)

8. Y.C. Chen, J. Jaczynski, J. Agr. Food. Chem., 55, 9079-9088 (2007)

9. A.D. Westphalen, J.L. Briggs, S.M. Lonergan, Meat. Sci., 72, 697-703 (2006)

10. T. Petcharat, S. Benjakul, Food. Hydrocolloid., 77, 746-753 (2018)

11. H.J. Alipour, M. Rezaei, B. Shabanpour, M. Tabarsa, Food. Hydrocolloid., 74, 87-96 (2018)

12. Y.K. Song, X. Zang, T. Kamal, J.R. Bi, S. Cong, B.W. Zhu, M.Q. Tan, Dry. Technol., 36, 72-83 (2018)

13. D.Q. Zhang, T.H. Mu, H.N. Sun, Carbohyd. Polym., 176, 345-355 (2017)

14. K. Konno, C. Fukazawa, J. Food. Sci., 58, 11981202 (1993)

15. T.A. Gill, J.T. Conway, Agric. Biol. Chem., 53, 2553-2562 (1989)

16. H.B. Mi, C. Wang, Q. Su, X.P. Li, S.M. Yi, J.R. Li, J. Texture. Stud., 50, 571-581 (2019)

17. H.M. Romero, D. Santra, D. Rose, Y. Zhang, J. Cereal. Sci., 74, 238-243 (2017)

18. B. Yu, F. Ren, H.B. Zhao, B. Cui, P.F. Liu, Int. J. Biol. Macromol., 142, 237-243 (2020)

19. I. Sánchez-Alonso, M.T. Solas, A.J. Borderías, J. Food. Eng., 81, 404-411 (2007).

20. N. Nishizawa, Y. Fudamoto, Biosci. Biotech. Bioch., 59, 333-335 (1995) 